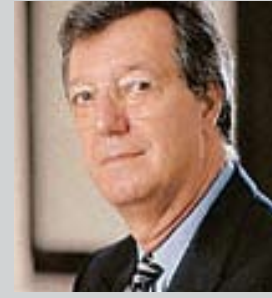

Carlos Osmar Bertero

FGV-EAESP carlos.bertero@fgv.br

\title{
projetodevida
}

\section{Saudosas carreiras?}

\section{O TRABALHO ASSALARIADO E AS CARREIRAS DE TIPO BUROCRÁTICO FORAM RECEBIDAS COM ALEGRIA EM UM PASSADO NEM TÃO DISTANTE}

A alegria com o advento do trabalho assalariado justifica-se porque a escravidão, com sua conhecida truculência, predominou durante boa parte de nossa história. Só com a Revolução Industrial os vestígios das relações servis começaram a desaparecer.

Já as carreiras de tipo burocrático, hoje retratadas como sinônimos de estagnação profissional ou peça obsoleta, foram arranjos que asseguravam empregos de longa duração - podendo, inclusive, chegar a ser vitalícios - e perspectivas de aumentos salariais seguidas de uma contrapartida em status e poder nas organizações. $\mathrm{Na}$ prática, nasceram do prolongamento, no mundo empresarial, de um tipo comum de carreira observada na esfera do Estado e da Igreja.

A carreira de tipo burocrático, ainda em vigor em algumas organizações (inclusive empresariais), consiste em uma montagem relativamente simples: a organização detém o poder de estabelecer a carreira, com seus níveis, conteúdos de cargos, remunerações e demais benefícios e as condições e critérios para entrada e promoção, bem como as regras para a saída. Em contrapartida, do funcionário ou do empregado espera-se adesão, obediência, fidelidade e adequação aos critérios.

Parte do mundo empresarial, no final do século passado, resolveu acabar com esse modelo secular de carreira e adotar, em seu lugar, a empregabilidade.

Agora a carreira, em princípio, deixa de ser controlada pela organização, passando inteiramente ao controle do empregado. Como conseqüência, cabe a ele ou ela a tarefa de aprimorar-se, progredir constantemente e mostrar-se empregável.

Contudo, será que, a despeito do discurso da empregabilidade (e do fim das carreiras), essa é a opção hegemonicamente preferida pelas pessoas quando comparada às carreiras burocráticas tradicionais? Como, então, explicar o aparente fascínio que, curiosamente, as carreiras no serviço público parecem ter voltado a exercer sobre os jovens? Inclusive, há, no Brasil, jornais especializados em concursos e, para certos cargos, como fiscais da Receita Federal, já houve provas que tiveram de ser realizadas em estádios de futebol...

E isso não parece prerrogativa apenas de país com tradição de Estado paternalista. Na França, cerca de dois terços dos jovens manifestam preferência por carreiras no serviço público. No meu modo de ver, tais fatos nos levam a refletir que ou não estão sendo formadas pessoas capazes de atuar em conformidade com os tempos (ditos pós-modernos) ou os tempos não estão em conformidade com as aspirações das pessoas. 